\title{
The Treatment of Aluminium Pigments with Inorganic Polymers for Environment-Friendly Applications
}

\author{
DRAGA DRAGNEA, DRAGOS GUDOVAN, ELENA ZAHARIA, COSTIN SORIN BILDEA* \\ University Politehnica Bucharest, Department of Chemical and Biochemical Engineering, 1-7 Polizu Str., 011061 Bucharest, \\ Romania
}

\begin{abstract}
Aluminium pigments are used in industrial and decorative coatings, automotive industry and printing inks. The encapsulation of aluminium pigments is used because the industry wants to avoid the organic solvents, for environmental reasons, by shifting towards water-borne systems. How ever, aluminium pigments easily react with water and a large amount of hydrogen is released leading to degradation of optical properties. This work presents experimental results concerning the encapsulation of aluminium pigments in silica matrices, by a sol-gel method using TEOS as precursor and ethylendiamine or ammonia as catalysts for the hydrolysis and condensation reactions. The samples of encapsulated pigments were characterized by gas stability tests: a boiling method and a gassing method.
\end{abstract}

Keywords: aluminium pigments, coatings, encapsulation, sol-gel process

Paints are widely used for decorative purposes [1]. Also, paints are used for protection of cars, ships, underground storage, vessels [2]. The coatings are a mixture of solvent which makes the paint spreadable, pigment for the paint colour and for corrosion protection, binder/resin which sticks the paint to the surface, and additives. Depending on their composition and the type of the solvent, paints are solvent-based, water-based or solvent-free. Solvent-based coatings contain a binder, a pigment, additives and an organic solvent, which form a homogeneous mixture; in water-based coatings the organic solvent is replaced by water, which forms an emulsion with the pigment, binder and additives; in solvent-free coatings the pigment and the additives are mixed into the resin [1,2].

The organic solvents are volatile organic compounds (VOC); therefore, they are atmosphere pollutants which produce environmental damage [3]. For this reason, the paint companies and researchers make tremendous efforts to develop water-based paints that are less toxic and more environment-friendly. Note that in the field of household paints the water-based and solvent-borne paints have the same performance.

Aluminium pigments (AP) are widely used in solventborne paints and printing inks. Due to their metallic appearance and low price $[4,5]$ this type of pigments can be used in plastic coatings, automotive coatings for refinishing and for parts and accessories, roof coatings, decorative coatings $[6,7]$. In the aluminium pigments industry, the problem is that AP reacts with water and a large amount of hydrogen is released, which damages the metallic aparence and can lead to explosion hazards.

This article focusses on encapsulation of aluminium pigments, which can provide a solution to this problem. The aluminium pigmentused in this study was provided by Alba Aluminiu Ltd., which is a paste and pigments producer. The encapsulation uses tetraethoxysilane (TEOS) as an inorganic pre-cursor. In the presence of water and a basic catalyst such as ammonia or ethylendiamine, TEOS undergoes a sequence of hydrolysis and condensation reactions (sol-gel process). As a result, the aluminium pigment is encapsulated in a matrix of inorganic polymer, which greatly enhances the resistance to water, while preserving the optical properties.

\section{The aluminium pigment}

The paints industry uses natural and synthetic pigments to provide a large spectrum of colours and a variety of finishes. The pigments have the purpose to provide the colour, the gloss, the opacity, corrosion inhibition and fireproofing properties of the paint. Additionally, the pigments increase the solid content of the coating or help the binder to stick.

The pigments can be organic or inorganic. The organic pigments are glossy, stable, have good transparency and great tinting strength. The inorganic pigments are cheaper than organic pigments, are heat and light stable and are used for corrosion protection. Also, the inorganic pigments are used to make speciality products (for example, with anticorrosion properties, black and white, or metallic appearance). Metal effect pigments [2] consist of small metal pellets (aluminium, titanium, copper, zinc, bronze) which act like little mirrors and reflect the incident light [8]. Another special effect pigment is pearl lustre pigment that simulates the lustre of natural pearls. This type of pigments alternates transparent layers with different refracting indices [8].

Aluminium pigments are widely used in the paints industry. They are manufactured (fig. 1) by milling of atomized aluminium powder, in a ball mill, with mineral spirit/white spirit and fatty acids [9-11].

The particles are shaped into very thin flakes, which enable superb hiding power and dispersion into various paints simply by mixing and blending. The lubricating additives determine the wetting behaviour of the pigment. When stearic acid is used, the metallic flakes float on the wet film, building a layer on the film surface (leafing pigments). This creates a characteristic metallic effect. The disadvantage of leafing effect is poor recoatability and low abrasion and corrosion resistance. When unsaturated fatty acids such as oleic acid are used as additives, the pigments are fully wetted and distribute homogeneously throughout the paint film (non-leafing pigments). Nonleafing pigments are better protected from abrasion and corrosion and can be easily over-coated. The metallic effect is based on the reflection of light on the smooth surface of the pigment. However, light scattering occurs at the edges of the flakes and due to the micro-roughness of the pigment surface.

\footnotetext{
*email : s_bildea@upb.ro
} 


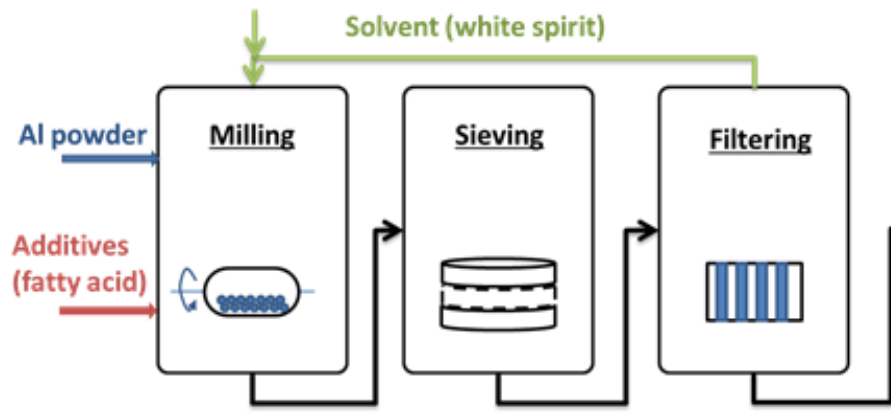

The optical appearance of the pigment is affected by following factors [12]:

-particle size (described as average diameter, D50); large particles promote brilliance. Fine particles give a more homogeneous effect due to light scattering, but the paint appears darker. Typical sizes are $8-25 \mu \mathrm{m}$ for usual applications, butcan be as small as $3 \mu \mathrm{m}$ for offset printing and as large as $50 \mu \mathrm{m}$ for high sparkle effect.

-particle shape/pigment morphology.

-particle size distribution. Fine and very fine particles lead to loss of metallic appearance, but too many coarse particles have a detrimental effect on the visual effects and during the application process.

- pigment orientation. The best metallic effect is obtained when the flakes arrange parallel to the surface [13]. A decisive role is played by the paint formulation and application conditions [14]. The pigment orientation leads to the flop-effect [15], meaning that the maximum brilliance is observable close to the gloss angle, while the object appears darker when view ed from a different angle. Three-dimensional objects such as car bodies appear much more sculpted and of higher quality.

In addition to optical properties, other requirements are related to mechanical properties [15], humidity resistance, intercoat adhesion, electrical resistance (in automotive parts [16]), shock-proof (in TV cabinet coatings), chemical resistance (in consumer electronics, appliances, automotive interior), weather resistance (for external use). Numerous aesthetical, physical and chemical requirements make the difference between low- and highvalue pigments. This short review clearly shows that aluminium pigments are complex products which must be carefully manufactured [17]. Their properties are determined by many characteristics of the raw material (for example, diameter and morphology of the atomized aluminium pow der [18]), the auxiliary materials (such as composition of the white spirit used during milling, content of oleic or stearic acid in the fatty-acid additive, $[19,20])$ and the detailed process conditions (for example solvent content of the filter cake).

Traditionally, aluminium pigments are used in solventborne formulations. However, the concerns about the human health and environment have pushed the industry to develop new environment-friendly products, such as water-based coatings. The problem is that AP reacts with water and a large amount of hydrogen is released. This is a very dangerous reaction which also damages the metallic appearance. The chemical reactions that may take place in a neutral, acid or base are the following $[5,21]$.

$$
\begin{aligned}
& 2 \mathrm{Al}+3 \mathrm{H}_{2} \mathrm{O} \rightarrow \mathrm{Al}_{2} \mathrm{O}_{3}+3 \mathrm{H}_{2} \\
& 2 \mathrm{Al}+6 \mathrm{H}_{2} \mathrm{O} \rightarrow 2 \mathrm{Al}(\mathrm{OH})_{3}+3 \mathrm{H}_{2} \\
& 2 \mathrm{Al}+6 \mathrm{H}^{+} \rightarrow 2 \mathrm{Al}^{3+}+3 \mathrm{H}_{2} \\
& 2 \mathrm{Al}+2 \mathrm{HO}^{-}+6 \mathrm{H}_{2} \mathrm{O} \rightarrow 2\left[\mathrm{Al}(\mathrm{OH})_{4}\right]^{-}+3 \mathrm{H}_{2}
\end{aligned}
$$

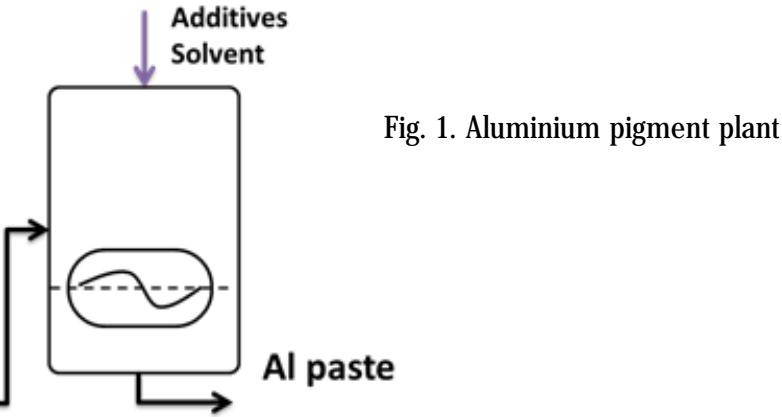

There are two ways to avoid these reactions [22]. One is by absorbing appropriate inhibitors on the surface of the aluminium pigment. Examples of inorganic inhibitors are vanadates, molybdates, phosphates, chromium (IV) complexes or other heavy metal based compounds [11, 21-23]. Using the inorganic inhibitors is an economical alternative for stabilization the aluminium pigment in aqueous media [24]. The drawback is that heavy metal compounds are toxic and carcinogenic [3]. For this reason, they are less and less used in the surface treatmentmethods [22]. Examples of organic inhibiting agents are low molecular-weight substances (phenols and aromatic acids), surfactants (alkyl phosphates, other anionic amphiphiles) and high molecular-weight compounds (polyelectrolytes). They contain a functional group that interacts specifically with the aluminium surface [25]. Du et al. [26] reviews the kinds of corrosive inhibitors used and their action mechanisms. Protective values of more than $99 \%$ were observed. Despite the verylarge number of organic inhibitors reported in the literature, their practical applicability is limited: the protective action is restricted to slightly alkaline medium ( $p H=8-10$ ); most of the organic inhibitors are expensive; no attention was paid to the optical, electrical and mechanical properties that are very important to practical applications.

A less toxic alternative is the encapsulation of the aluminium pigment [27], which involves the formation of a polymer protective layer around the aluminium flake [28] .

\section{Encapsulation methods}

The encapsulation of aluminium pigment can be achieved using inorganic, organic or inorganic-organic polymers [29]. To encapsulate with organic polymers, insitu polymerization is used. For inorganic and inorganicorganic encapsulation, the environment-friendly sol-gel process is used.

\section{Sol-gel process}

Generally, the sol-gel method is used to synthesize an inorganic nanostructure network by hydrolysis and condensation reactions of a silane. During the process, covalent bonds are formed between substrate surface and the inorganic nanostructure [22]. This process is strongly influenced by temperature and $\mathrm{pH}$ [30].

The precursors used for sol-gel process are alkoxides, amongst which tetraethoxysilane (TEOS) is the most used one [31]. TEOS is a special case of silane because it forms a $\mathrm{SiO}_{2}$ network without organic modification [30]. The encapsulation process consists of depositing a $\mathrm{SiO}_{2}$ layer on the aluminium pigment surface (fig. 2).

In the first step, the alkoxide hydrolyses and silanols are formed. Then, the condensation reaction takes place, where water is eliminated and siloxanic bonds are formed. Then, the macromolecules are linked with the substrate by hydrogen bonds. Finally, more water is removed and the pigment encapsulated in silica layer is obtained. 


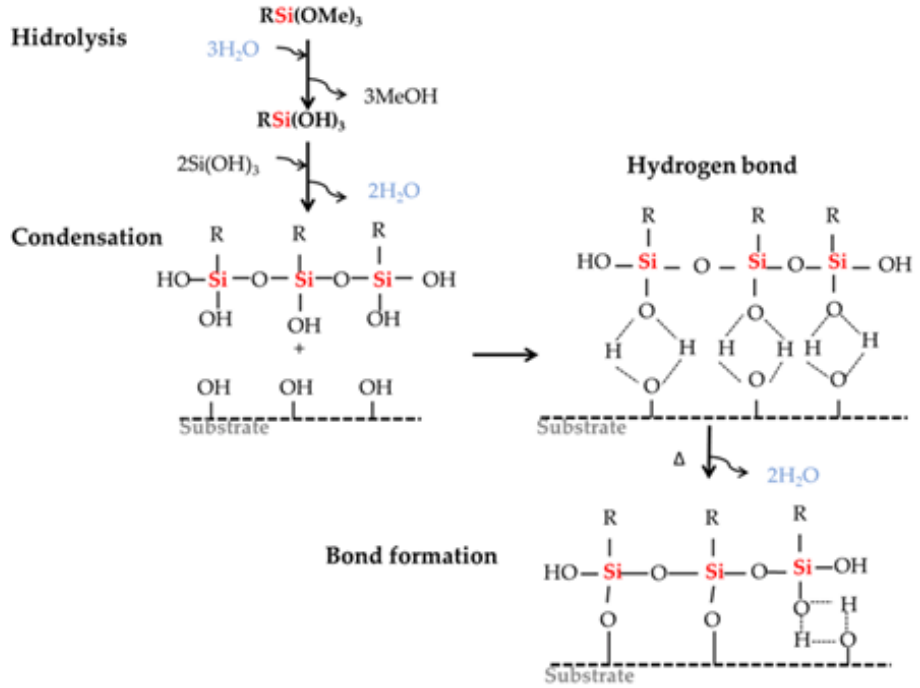

Eqs. (5-7) represent the hydrolysis and condensation of the alkoxides.

Hydrolysis

$$
-\mathrm{Si}_{\mathrm{i}}-\mathrm{OR}+\mathrm{H}_{2} \mathrm{O} \leftrightarrow-\mathrm{Si}_{\mid}-\mathrm{OH}+\mathrm{ROH}
$$

Si-bonding, water forming condensation

$$
-\mathrm{S}_{i}-\mathrm{OH}+-\mathrm{Si}_{1}-\mathrm{OH} \leftrightarrow-\mathrm{S}_{1}-\mathrm{O}-\mathrm{S}_{\mathrm{i}} \mathrm{i}-+\mathrm{H}_{2} \mathrm{O}
$$

\section{Si-bonding, alcohol forming condensation}

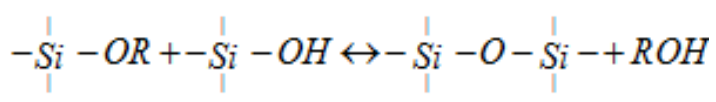

\begin{tabular}{|c|c|}
\hline Precursor & Main results \\
\hline Tetraethoxysilane (TEOS), $[5,6]$ & $\begin{array}{l}\text {-corrosion protection factor: } 99.3 \% \\
\text {-small change of the average grain size after coating } \\
\text {-characterization by FTIR, EDS, SEM, AFM, BET } \\
\text {-the effects of medium of reaction, adding sequence of catalyst and number of coating } \\
\text { were investigated. Stability tests confirmed improved corrosion resistance. }\end{array}$ \\
\hline $\begin{array}{l}\text { Tetraethoxysilane (TEOS) } \\
\text { Tris(2-methoxyethoxy) vinylsilane } \\
\text { (VTMOEO), [7] }\end{array}$ & $\begin{array}{l}\text {-water-ethanol solution } \\
\text {-the influences of the precursor, catalyst and solvent dosage, as well as the reaction } \\
\text { temperature and reaction time on the corrosion inhibition efficiency were } \\
\text { investigated. } \\
\text {-corrosion inhibition efficiency reached } 99.2 \% \text { in alkaline media of } \mathrm{pH}=11 \\
\text {-characterization by SEM, FTIR, EDS, XPS }\end{array}$ \\
\hline $\begin{array}{l}\text { Tetraethoxysilane(TEOS) } \\
\text { Vinyltriethoxysilane(VTES) } \\
{[31,35]}\end{array}$ & $\begin{array}{l}\text {-a dense netlike layer is formed on the surface of aluminium pigments, where TEOS } \\
\text { and VTES are successfully bonded to } \mathrm{Al} \text { surface. New Si-O-Al groups are observed. } \\
\text {-corrosion protection efficiencies of } 99.8 \% \text { at } \mathrm{pH}=1 \text { and } 99.9 \% \text { at } \mathrm{pH}=11 \text {. } \\
\text {-characterization by FTIR, SEM, XPS }\end{array}$ \\
\hline $\begin{array}{l}\text { Tetraethoxysilane (TEOS) } \\
\text { Hexadecyltrimethoxysilane } \\
\text { Dimethyldimethoxysilane } \\
{[22]}\end{array}$ & $\begin{array}{l}\text {-aluminium flakes were coated with a silica layer (TEOS as precursor), followed by } \\
\text { condensation of hexadecyltrimethoxysilane or dimethyldimethoxysilane. } \\
\text {-anticorrosive properties in alkaline solutions and under boiling water conditions. }\end{array}$ \\
\hline $\begin{array}{l}\text { Tetraethoxysilane (TEOS) } \\
\text { Titanium tetrabutoxide (TBT) [27] }\end{array}$ & $\begin{array}{l}\text { - aluminium pigments coated with } \mathrm{SiO}_{2} \text { and then with } \mathrm{TiO}_{2} \text {. } \\
\text {-the stability of the product in acid was examined by measuring the volume of } \\
\text { generated hydrogen } \\
\text {-properties characterized by FTIR, SEM and EDS. }\end{array}$ \\
\hline
\end{tabular}

\section{Table 1}

INORGANIC ENCAPSULATION OF ALUMINIUM PIGMENTS

Fig. 2. The mechanism of encapsulation by the sol-gel method, with alkyl trimetoxy silane as alkoxide precursor [32]

Eqs. (8-9) are the reactions between the hydrolysed / non-hydrolysed silane and metal.

Al-bonding, water forming condensation

$$
-\mathrm{Si}_{\mathrm{i}}-\mathrm{OH}+\mathrm{Al}-\mathrm{OH} \leftrightarrow-\mathrm{Si}_{i}-\mathrm{O}-\mathrm{Al}+\mathrm{H}_{2} \mathrm{O}
$$

Al-bonding, alcohol forming condensation

$$
-\mathrm{Si}_{i}-\mathrm{OR}+\mathrm{Al}-\mathrm{OH} \leftrightarrow-\mathrm{Si}_{i}-\mathrm{O}-\mathrm{Al}+\mathrm{ROH}
$$

Inorganic encapsulation of aluminium pigments

The inorganic route is dominated by coating with silica, leading to aluminium pigments that are comparable in performance to chromate-inhibited pigments and offering a heavy metal-free alternative [25]. . 
The sol/gel process [33] provides pigments with longterm stability in water-based coatings and excellentoptical properties. No degradation under high shear stress was observed, a property which is important in the automotive industry. Moreover, the silica-coated pigments show an excellent weather fastness and good adhesion when the pigmented coatings are exposed to humidity tests [34].

During encapsulation, a polymer layer is formed at the surface of the aluminium pigment. When the silanes contain reactive groups such as vinyl, amino, epoxy or thiol, the inorganic layer can promote attachment of organic polymers to the metallic surface.

Several alkoxides were used as precursors. The reactions were carried on in the presence of ethylendiamine as catalyst, in water-ethanol solutions. Good corrosion properties were observed. Table 1 presents an overview of the results reported in the literature.

For industrial applications, the cost, the availability and the toxicity of raw materials is very important. Therefore, TEOS has potential for large scale applications, while the other alkoxides could be used as precursor in small scale or very special applications. The next sections give few details about other encapsulation methods.

\section{Organic encapsulation of aluminium pigments}

The emulsion polymerization-like process for the encapsulation of commercial aluminium was suggested as a way to improve the performance of aluminium pigment in waterborne coatings [36]. Analytical investigations by SEM, TEM, STEM-EDX, XPS, and TOC were performed and revealed the coagulation of polymer particles on the pigment surface. Moreover, increased stability of the aluminium pigments in the presence of alkaline water was demonstrated [36].

\section{Inorganic-organic encapsulation of aluminium pigments}

Materials in which a layer of organic material surrounds an inorganic particle core have been investigated as a means to improve the stability and surface chemistry of the core particle. They aim to circumvent a) poor compatibility of $\mathrm{SiO}_{2}$ coatings with resins and organic compounds found in water-borne coatings; b) poor adhesion of the organic polymer to the metallic surface. Because of their unique properties, the fabrication of coreshell particles is attracting a great deal of interest [44]. table 3 summarizes the results concerning encapsulation of aluminium pigments in composite matrices.

Table 2

ORGANIC ENCAPSULATION OF ALUMINIUM PIGMENTS

\begin{tabular}{|c|c|}
\hline Polymer & Main results \\
\hline $\begin{array}{l}\text { Acrylic resin } \\
\text { (containing hydroxyl groups) [37] }\end{array}$ & $\begin{array}{l}\text { After removal of the fatty acid from the surface of aluminium particles by washing } \\
\text { with ethanol solution, aluminium particles can be encapsulated in hydroxyl group- } \\
\text { containing acrylic resin by chemosorption. The encapsulated aluminium pigments } \\
\text { have excellent adhesive performance in the paint film. }\end{array}$ \\
\hline Polyacrylic acid [38] & $\begin{array}{l}\text { Composite particles were prepared by in-situ polymerization. The influences of } \\
\text { dosage of acrylic acid, ammonium persulphate, isopropanol and water, as well as } \\
\text { reaction temperature and reaction time, on corrosion inhibition efficiency and gloss } \\
\text { were investigated. Maximum corrosion inhibition efficiency was } 99.7 \% \text {. Using TGA, } \\
\text { SEM, laser particle size analysis, FTIR and XPS, polyacrylic acid was found to be } \\
\text { coated on the surface of clear aluminium particles. }\end{array}$ \\
\hline $\begin{array}{l}\text { Poly(methyl methacrylate) (PMMA) } \\
\text { [39] }\end{array}$ & $\begin{array}{l}\text { PMMA / flaky aluminium composite particles were prepared by in situ emulsion } \\
\text { polymerization of methyl methacrylate (MMA), as demonstrated by FTIR and EDS. } \\
\text { Evolved hydrogen detection showed that corrosion resistance of aluminium pigments } \\
\text { had been remarkably improved. }\end{array}$ \\
\hline $\begin{array}{l}\text { Poly(methyl methacrylate) (PMMA) } \\
{[40]}\end{array}$ & $\begin{array}{l}\text { PMMA coating was applied on aluminium pigment particles by polymerization of } \\
\text { MMA. A surfactant (sodium dodecyl sulfate) is first adsorbed on the aluminium } \\
\text { pigment surface and a hydrophobic monomer and initiator (benzoyl peroxide) is } \\
\text { subsequently solubilized inside the hydrophobic domain of the surfactant aggregates } \\
\text { that cover the pigment. PMMA was formed on the pigment particles. The amount of } \\
\text { organic material was up to } 24 \% \text { of the particle weight. Good protection from an } \\
\text { alkaline solution was obtained. }\end{array}$ \\
\hline $\begin{array}{l}\text { Poly(methyl methacrylate) (PMMA) } \\
\text { [41] }\end{array}$ & $\begin{array}{l}\text { With ammonium persulfate as the initiator, the kinetics of grafting polymerization } \\
\text { onto flaky aluminium powder was studied. The experimental apparent grafting } \\
\text { polymerization rate was determined and the activation energy of grafting, } \\
\text { homogenous and total polymerization rates were calculated. }\end{array}$ \\
\hline $\begin{array}{l}\text { Poly(methyl methacrylate) (PMMA) } \\
\text { [4] }\end{array}$ & $\begin{array}{l}\text { PMMA grafted aluminium powder was prepared by surface-initiated in situ } \\
\text { polymerization. The process was divided into two steps: adsorption of the initiator } \\
\text { and polymerization of the monomer. The percentage of adsorption and adsorption } \\
\text { efficiency were } 31.2 \% \text { and } 52.0 \% \text {, respectively. }\end{array}$ \\
\hline $\begin{array}{l}\text { Poly(trimethylolpropane triacrylate) } \\
\text { aluminium }[42,43]\end{array}$ & $\begin{array}{l}\text { Composite particles were prepared by in situ polymerization. The effect of monomer } \\
\text { concentration, initiator concentration and feeding mode on conversion, percentage of } \\
\text { grafting and grafting efficiency was studied. It was found that poly } \\
\text { (trimethylolpropane triacrylate) had been successfully grafted on the surface of flaky } \\
\text { aluminium through chemical bond. Evolved hydrogen detection and pulling } \\
\text { experiments showed that the corrosion resistance and adhesive property of composite } \\
\text { particle had been markedly enhanced. }\end{array}$ \\
\hline
\end{tabular}


Table 3

INORGANIC-ORGANIC ENCAPSULATION OF ALUMINIUM PIGMENTS

\begin{tabular}{|c|c|}
\hline $\begin{array}{l}\begin{array}{l}\text { Inorganic precursor } / \\
\text { polymer }\end{array} \\
\text { organic } \\
\end{array}$ & Main results \\
\hline $\begin{array}{l}\text { Tetraethoxysilane (TEOS) } \\
\text { Vinyltriethoxysilane(VTES) } \\
\text { Styrene (ST) } \\
\text { Divinylbenzene (DVB) Maleic acid } \\
\text { anhydride(MA) } \\
{[45]}\end{array}$ & $\begin{array}{l}\text { Encapsulated aluminium pigments were prepared by sol-gel derived inorganic- } \\
\text { organic hybrid coatings. Aluminium pigments were first coated with sol-gel film by } \\
\text { using TEOS and VTES as precursors, followed by free radical copolymerization of } \\
\text { ST, DVB and MAA with the vinyl group of the VTES. The encapsulated aluminium } \\
\text { pigment was characterized by FTIR, SEM and XPS. The coated aluminium pigments } \\
\text { were superior in the stability test over the uncoated aluminium pigments. } \\
\text { Furthermore, the corrosion protection efficiency reaches } 99.8 \% \text {, indicating the } \\
\text { protective action of the inorganic-organic hybrid composite layer. }\end{array}$ \\
\hline $\begin{array}{l}\text { Vinyltriethoxysilane(VTES) } \\
\text { Polyacrylate (PA) } \\
{[23,46]}\end{array}$ & $\begin{array}{l}\text { Double-layer coated aluminium pigments were prepared by first encapsulating } \\
\text { through sol-gel method into } \mathrm{SiO}_{2} \text { with active vinyl groups } / \mathrm{SiO}_{2} \text {, and then coating } \\
\text { with polyacrylate by in-situ polymerization. The encapsulated aluminium pigments } \\
\text { were characterized by means of FTIR and SEM. The stability of coating films } \\
\text { containing } \mathrm{PA} / \mathrm{SiO} / \mathrm{Al} \text { pigments in acid aqueous media, the gloss of films, the } \\
\text { dispersion and adhesion of } \mathrm{PA} / \mathrm{SiO}_{2} / \mathrm{Al} \text { pigments in resins were characterized. } \\
\text { Uniform and compact } \mathrm{SiO}_{2} \text {-polymeric films have been formed. }\end{array}$ \\
\hline $\begin{array}{l}\text { Tetraethoxysilane (TEOS) } \\
\text { Acrylate-silane resin (PMBV, } \\
\text { PMBK) } \\
{[47,48,49]}\end{array}$ & $\begin{array}{l}\text { Aluminium sheet was encapsulated by inorganic-organic hybrid film through a base } \\
\text { catalysed sol-gel method using PMBV/PMBK and TEOS as precursors. PMBV } \\
\text { PMBK was formed in advance by co-polymerisation of methyl methacrylate } \\
\text { (MMA), n-butyl acrylate (BA) and vinyl triethoxysilane (VTES) or vinyl } \\
\text { trimethoxysilane (VTMS). FTIR and AFM characterizations proved that PMBV and } \\
\text { TEOS have hydrolysed and co-condensed with each other to form a uniform film on } \\
\text { the surface of aluminium sheet. XPS showed that hydroxyl groups on aluminium } \\
\text { surface took part in the co-condensation reaction. The encapsulated aluminium } \\
\text { pigments were further characterised by means of SEM, TG and XPS }\end{array}$ \\
\hline
\end{tabular}

\section{Experımental part}

\section{Materials and methods}

The encapsulation experiments were performed on aluminium pigments produced by Alba Aluminiu Ltd. Before encapsulation experiments, the AP were washed with isopropanol and dried at $80^{\circ} \mathrm{C}$. The non-leafing special pigment used is commercially available under the name of Alba Aluminiu Metal 50. It shows a metallic effect, given by the pigment capacity to change the tint depending on angle of view. This characteristic is called flop effect. The particles shape of Metal 50 product is cornflake. Metal 50 has an average grain size, D50 21 $\mu \mathrm{m}$, being used for auto refinishing, auto parts and accessories, plastics, metallic carpentry.

Tetraethoxysilane (TEOS) 98\%, ammonia 25\%, ethylendiamine, ethylene glycol butyl ether $99 \%$ from Sigma Aldrich Ltd, and isopropanol 99.9\% from Chimreactiv Ltd were used as received.

\section{a. The encapsulation process}

The aluminium pigment and TEOS dispersed in isopropanol was introduced into a three-neck round-bottom

flask which was connected to a condenser, a thermometer and a stirrer (fig. 3). Several experiments were performed, with Al/TEOS mass ratio ranging from 1:0.5 to 1:1.5. The flask was heated in a thermostatic bath, at temperature between 30 and $60^{\circ} \mathrm{C}$. After heating, the basic catalyst (ammonia or ethylendiamine) was added.

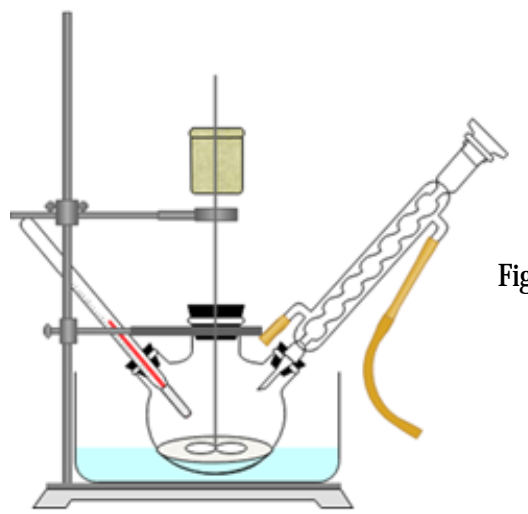

Fig. 3. Laboratory set-up for encapsulation process
After the reaction takes place, the encapsulated pigment is separated by decanting and dried under vacuum at $80^{\circ} \mathrm{C}$.

The encapsulated aluminium pigments can be characterized by physical and industrial methods.

\section{b. Physical characterisation methods}

The physical characterization methods include:

-Scanning Electron Microscopy SEM, which uses a focused beam of high-energy electrons to generate a variety of signals at the surface of solid samples. The signals that derive from electron-sample interactions reveal information such as: morphology, chemical composition, crystalline structure and orientation of materials making up the sample. The differences between the untreated aluminium pigment and encapsulated aluminium pigment can be observed. In this work, the SEM analysis were performed using a Vega 3 LMH model equipped with SE, BSE detectors and EDX spectrometer, produced by Tescan. It is a fully PC controlled SEM with conventional tungsten heated cathode working in high vacuum.

-Transmission Electron Microscopy TEM, is a method that reveals the thickness of the polymer layer on the aluminium pigment surface.

-Fourier Transform Infrared Spectroscopy FTIR is a technique that gives an infrared spectrum of absorption or emission of a sample. The spectrum of an encapsulated aluminium pigment shows the vibration bands for Si-O-Al, $\mathrm{Si}-\mathrm{O}-\mathrm{Si}$ and $\mathrm{Si}-\mathrm{OH}$ bonds.

-Thermogravimetry Analysis TGA is a method that measures the changes in physical and chemical properties of the sample as temperature is increased. This method offers information about temperature stability of the layer around the aluminium flake.

It should be emphasized that the hiding power of aluminium pigments is due to their ability to reflect the incident light, which confers opacity to the system in which they are embedded. For this reason, a quick but important test used by industry consists in comparing the hiding power of the encapsulated AP with the hiding power of the original (raw material) AP.

Aluminium pigments easily react with water and a large amount of hydrogen gas is released. It is a must to avoid 
this reaction and it is very important to measure the quantity of hydrogen produced. From the industry point of view, characterizing the stability of encapsulated aluminium pigments is a very important issue. The stability test, which measures the quantity of hydrogen released in a certain period of time, will be described in the following section.

\section{c. Stability testing methods}

The industrial standard for testing the stability of aluminium pigments, as applied by Alba Aluminiu Ltd, is known as the gassing method (fig. 4). The encapsulated aluminium pigment dispersed in the water-based coating is added in a flask, which is heated in a water bath. The flask is connected to a two-chambers recipient. The lower chamber is filled with water. When hydrogen is released due to the chemical reaction, it forces the water from the lower to the upper chamber. This method measures the released hydrogen in 7 - 14 days at a temperature between 40-60 ${ }^{\circ} \mathrm{C}$.

The drawback of this method is the long analysis time required. This is inconvenient for the research activities, when many samples are prepared and must be tested. Therefore, a simple boiling method was set-up as a fast screening tool for checking the stability of encapsulated samples (fig. 5). Encapsulated AP dispersed in butyl glycol

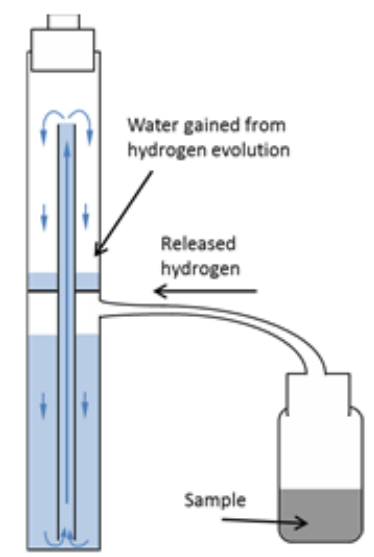

Fig. 4. Industrial method for stability testing (gassing method)

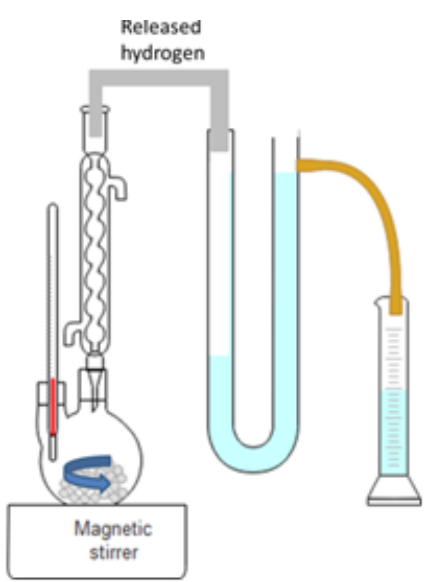

Fig. 5. Laboratory method for quick stability testing (boiling method) is added into a two-neck flask with water inside. The mixture is heated to high temperature (for example, $95^{\circ} \mathrm{C}$ ), which is controlled by means of a thermostat. The flask is on top of a magnetic stirrer and has attached a thermometer to measure the temperature and a condenser for the water vapors. The condenser has attached a tube filled with water which connects to a storage tank that allows to measure the volume of water displaced by hydrogen.

Due to higher temperature, the rate of aluminium - water reaction is much larger compared to the gassing method. Therefore, measurable volumes of hydrogen are released in a shorttime, which makes the method suitable for quick testing of the AP stability. Note that, for the same amount of released hydrogen, the measured volume is temperaturedependent. Therefore, when the stability of different Alpigment samples is compared, the stability tests should be performed at the same temperature, or the temperature must be measured and the volumes corrected accordingly.

\section{Results and discussions \\ Encapsulation}

The mechanism of the encapsulation process is presented in figure 2 . The important parameters that influence this process are $\mathrm{pH}$ and temperature, which determine the crosslinking and the silica layer thickness. Basic catalysts such as ammonia or ethylendiamine where used to adjust the $\mathrm{pH}$ value.

The encapsulated sample were analysed by SEM to reveal the morphology of the flakes after encapsulation. Figure 6 shows the difference between raw material and encapsulated AP. It can be seen that the encapsulated sample is like a cloud, meaning that a silica layer was formed around the aluminium flake.
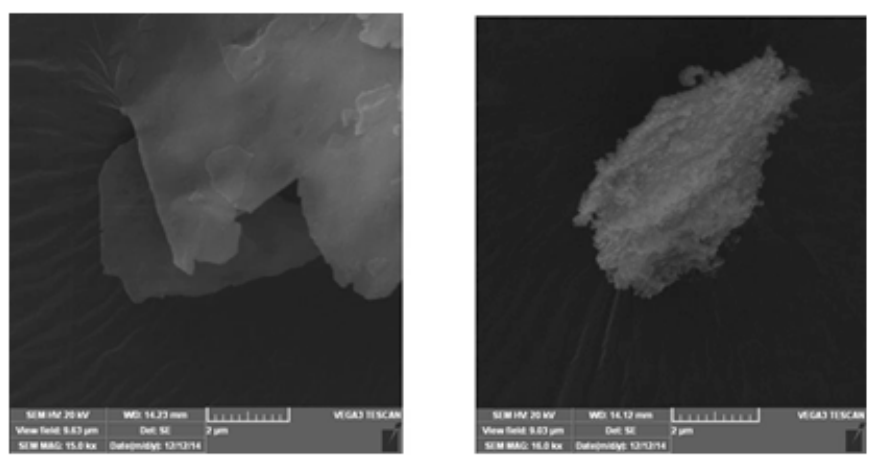

Fig. 6. SEM analysis for raw material (left) and encapsulated sample (right)

After the encapsulation process is finished, a very quick and useful test checks the hiding power of the encapsulated pigment. If the hiding power is good, itmeans that the opacity of the paint is good, and it can be used to cover a substrate. Figure 7 shows the difference between the hiding power of the raw material and of two

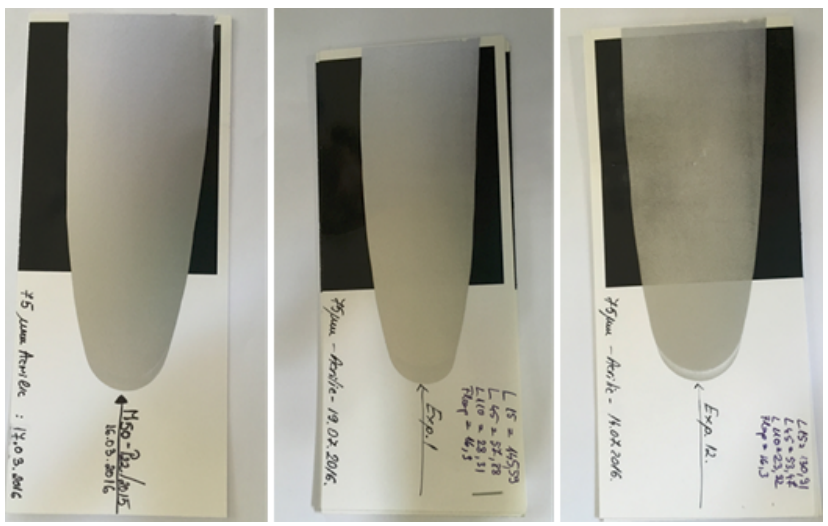

Fig. 7. Hiding power of the raw material (left); encapsulated sample with good hiding power (middle); encapsulated sample with poor hiding power (right) 


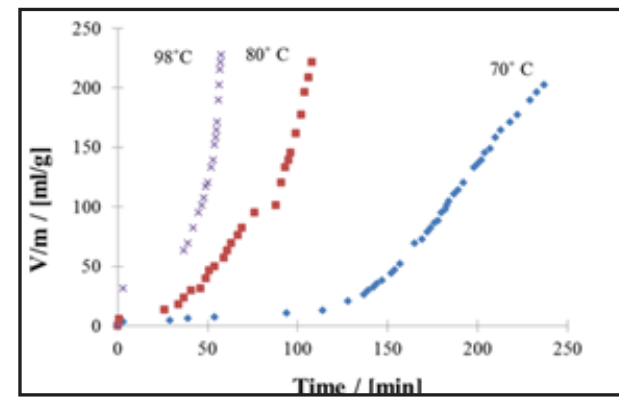

encapsulated samples, one with good hiding power and the other one with poor hiding power. In the right example, it can see that the opacity of the paint is insufficient to hide the substrate.

\section{Stability}

The result of gassing stability test in water-based coating performed by Alba Aluminiu Ltd was that encapsulated aluminium pigment release $5 \mathrm{~mL}$ of hydrogen in one week. Comparatively, aluminium pigments protected by heavymetal inhibitors release about $15 \mathrm{~mL}$ of hydrogen in one week.

The results of boiling stability test are presented in the figure 8. The plots show the amount of hydrogen released by $1 \mathrm{~g}$ of pigment during time; it can be observed that a large quantity of hydrogen is released because the pigment is unstable in water (left). Also, the release of hydrogen is faster at higher temperature. The stability test for encapsulated aluminium pigment was performed at $95^{\circ} \mathrm{C}$. The plot (right) shows that the encapsulation greatly enhanced the stability of the pigment. Also, the stability of aluminium pigment protected by encapsulation is as good as the stability of the aluminium pigment protected by heavy-metal inhibitors (right).

\section{Conclusions}

Environment-friendly aluminium pigments that can be used in water-based coatings can be obtained encapsulation in a $\mathrm{SiO}_{2}$ inorganic polymer. The encapsulation is based on sol-gel process which is an economical technology that is suitable for industrial applications. From the environment point of view, the solvent (isopropanol, n.b.p. $82.6^{\circ} \mathrm{C}$ ) and the catalyst (ethylenediamine, n.b.p. $116^{\circ} \mathrm{C}$ ) can be easily recovered by distillation and re-used in the process.

The boiling stability test is a quick method that has good, reliable results which are confirmed by industrial stability method. The stability of the $\mathrm{SiO}_{2}$ - encapsulated aluminium pigment is the same as the stability of the aluminium pigment inhibited with toxic and carcinogen heavy-metal compounds.

Acknowledgement: The financial support of the project Innovative processes for encapsulation of aluminium pigments in polymer matrices, PN-II-PT-PCCA-2013-4-2069, contract 233/2014 is gratefully acknowledged

\section{References}

1.DUIVENVOORDE, F. L., PhD Thesis, Technische Universiteit Eindhoven, Eindhoven, 2000;

2.CLARK, M. D. T., Paints and Pigments, 2002, On line at: http:// nzic.org.nz/ChemProcesses/polymers/10D.pdf;

3.00IJ, W. J., ZHU, D., STACY, M., SETH, A., MUGADA, T., GANDHI, J., PUOMI, P., Tsinghu Science and Technology, 10, 2005, p. 639-664; 4.LIU, H., YE, H., TANG, X., Applied Surface Science, 254, 2007, p. 616620.;
Fig. 8. Results of boiling stability tests. The stability of raw material at different temperature (left) and the stability of protected $\mathrm{AP}$ at $95^{\circ} \mathrm{C}$ (right)
5.WANG, H., HUANG, S. L., ZUO, Y. J ., ZHOU, T., ZHANG, L. R., Corrosion Science, 53, 2011, p. 161-167;

6.ZHANG, Y. C., YE, H. Q., LIU, H., HAN, K., Corrosion Science, 53, 2011, p. 1694-1699;

7.ZHU, H. W., QU, X. Y., HU, Y., XIE, H., CHEN, Z. X., Corrosion Science, 53, 2011, p. 481-486;

8.MIRHABIBI, A. R., Ceramic Coatings for Pigments, Ceramic Coatings - Applications in Engineering, Prof. Feng Shi (Ed.), InTech, 2012. On line at: http://www.intechopen.com/books/ceramic-coatingsapplications-in-engineering/ceramic-coatings-for-pigments;

9.HONG, S. H., LEE, D. W., KIM, B. K., J ournal of Materials Processing Technology, 100, 2000, p. 105-109;

10.HONG, S. H., KIM, B. K., Materials Letters, 51, 2001, p. 139-143;

11.KARLSSON, P., BAEZA, A., PALMQVIST, A. E. C., HOLMBERG, K., Corrosion Science, 50, 2008, p. 2282-2287

12.MORRISON, S., Surface Coatings International, 92, 2009, p. 68-77;

13.KIRCHNER, E., Progress in Organic Coatings, 65, 2009, p. 333-336; 14.GUNDE, M. K., KUNAVER, M., HROVAT, A., CVELBAR, U., Progress in Organic Coatings, 54, 2005, p.113-119;

15.KARBASI, A., MORADIAN, S., TAHMASSEBI, N., GHODSI, P., Progress in Organic Coatings, 57, 2006, p. 175-182;

16.ATHANASSIOU, E. K., GRADISCHNIG, H., SIEMSEN, P., STARK, W. J., Industrial \& Engineering Chemistry Research, 48, 2009, p. 8944-8949; 17.HILL, L. W., Progress in Organic Coatings, 10, 1982, p. 55-89;

18.ESUMI, K., J ournal of Colloid and Interface Science, 241, 2001, p. 117 ;

19.PERTAYS, K. M., THOMPSON, G. E., ALEXANDER, M. R., Surface and Interface Analysis, 36, 2004, p. 1361-1366;

20.DU, B., ZHOU, S. S., WANG, N., Advanced Materials Science and Technology, 181-182, 2011, p. 679-684;

21.AMIRSHAQAQI, N., SALAMI-KALAJAHI, M., MAHDAVIAN, M., Corrosion Science, 87, 2014, p. 392-396;

22.SUPPLIT, R., SCHUBERT, U., Corrosion Science, 49, 2007, p. 33253332;

23.HE, Y., LI, H., OU, L., DING, F., ZHAN, Z., ZHONG, Y., Corrosion Science, 111, 2016, p. 802-810;

24.ALVAREZ, D., COLlAZO, A., NOVOA, X. R., PEREZ, C., Progress in Organic Coatings, 96, 2016, p. 3-12;

25.KARLSSON, P., PALMQVIST, A. E. C., HOLMBERG, K., Advances in Colloid and Interface Science, 128, 2006, p. 121-134;

26.DU, B., ZHOU, S. S., WANG, N., Applied Mechanics and Materials, 80-81, 2011, p. 70-75;

27.ZHOU, L., HUANG, S. L., KONG, J. R., ZHOU, T., ZUO, Y. J., Powder Technology, 237, 2013, p. 514-519;

28.MA, Z. L., LI, C. C., WEI, H. M., DING, D. Q., Dyes and Pigments, 114,2015, p. 253-258;

29.NIROUMANDRAD, S., ROSTAMI, M., RAMEZANZADEH, B., Applied Surface Science, 357, 2015, p. 2121-2130;

30SEPEUR, S., Silane-technology as the key to Chemical Nanotechnology, In: Nanotechnology: Technical Basics and Applications, Vincentz Network, Hannover, 2008, p. 19-29;

31.LI, L. J., PI, P. H., WEN, X. F., CHENG, J., YANG, Z. R., J ournal of Central South University of Technology, 14, 2007, p. 37-41;

32.ARKLES, B., Silane Coupling Agents: Connecting across boundaries, Gelest, Inc., 2006;

33.KIEHL, A., BRENDEL, H., Macromolecular Symposia, 187, 2002, p. 109-120; 
34.KIEHL, A., GREIWE, K., Progress in Organic Coatings, 37, 1999, p. 179-183;

35.LI, L. J., PI, P. H., WEN, X. F., CHENG, J., YANG, Z. R., Corrosion Science, 50, 2008, p. 795-803;

36.BATZILLA, T., TULKE, A., J ournal of Coatings Technology, 70, 1998, p. 77-83;

37.PI, P. H., CHEN, J., CHEN, K., CAI, Z. Q., ZHENG, D. F., WEN, X. F., CHENG, J., YANG, Z. R., Canadian J ournal of Chemical Engineering, 90, 2012, p. 1224-1230;

38.ZHU, H. W., CHEN, Z. X., SHENG, Y., THI, T. T. L., Dyes and Pigments, 86, 2010, p. 155-160;

39.LIU, H., YE, H. Q., LIN, T. Q., ZHOU, T., Particuology, 6, 2008, p. 207213;

40.KARLSSON, P., ESBJ ORNSSON, N. B., HOLMBERG, K., J ournal of Colloid and Interface Science, 337, 2009, p. 364-368;

41.LIU, H., SUN, R., YI, J. H., YE, H. Q., TANG, X. D., LI, Y. F., J ournal of Applied Polymer Science, 115, 2010, p. 3040-3044;
42.LI, L. J., PI, P. H., WEN, X. F., CHENG, J., YANG, Z. R., J ournal of Coatings Technology and Research, 5, 2008, p. 77-83;

43.LIU, H., YE, H. Q., ZHANG, Y. C., Colloids and Surfaces aPhysicochemical and Engineering Aspects, 315, 2008, p. 1-6;

44.CAO, S. S., CHEN, J. R., HU, J., Australian J ournal of Chemistry, 62, 2009, p. 1561-1576;

45.LIU, H., YE, H. Q., Applied Surface Science, 254, 2008, p. 4432-4438; 46.GAO, A. H., PI, P. H., WEN, X. F., CHENG, J. A., YANG, Z. R., $8^{\text {th }}$ International Conference on Measurement and Control of Granular Materials, Proceedings, 2009, p. 192-195;

47.GAO, A. H., PI, P. H., CHENG, J., YANG, Z. R., New Materials, Applications and Processes, 399-401, 2012, p. 390-393;

48.GAO, A. H., PI, P. H., WEN, X. F., ZHENG, D. F., CAl, Z. Q., CHENG, J., YANG, Z. R., Pigment \& Resin Technology, 41, 2012, p. 149-155; 49.PI, P., LIU, C., WEN, X., ZHENG, L., XU, S., CHENG, J., Particuology, 19, 2015, p. 93-98.

Manuscript received: 23.02 .2018 